Article

\title{
A Review of Carbon Capture and Storage Project Investment and Operational Decision-Making Based on Bibliometrics
}

\author{
Jiaquan $\mathrm{Li}^{1,2, *}$, Yunbing Hou ${ }^{1}$, Pengtao Wang ${ }^{1,2}$ and Bo Yang ${ }^{1,2}$ \\ 1 College of Resources and Safety Engineering, China University of Mining and Technology (Beijing), \\ Beijing 100080, China; hyb@cumtb.edu.cn (Y.H.); BQT1700101031@student.cumtb.edu.cn (P.W.); \\ TBP1600101020@student.cumtb.edu.cn (B.Y.) \\ 2 Center for Energy and Environmental Policy Research, Beijing Institute of Technology, Beijing 100081, China \\ * Correspondence: TBP150101018@student.cumtb.edu.cn; Tel.: +86-10-6891-8651
}

Received: 1 December 2018; Accepted: 18 December 2018; Published: 21 December 2018

\begin{abstract}
The research on carbon capture and storage (CCS) project planning and investment and operational decision-making can provide a reference for enterprises to invest in CCS and for policy-makers to formulate policies to promote CCS development. So what are the current research hotspots in this field and the gaps that still need to be further studied in the future? This paper reviews the research in the field by a bibliometric analysis. The results show that the research in this field first focus on cost analysis, followed by project investment evaluation, project planning (cost curve and pipeline network), and project operation. In particular, fossil fuel power plants, pipeline transportation, and oil fields are the most crucial objects in the three technical links of CCS projects, respectively. Policies, carbon pricing, and uncertainty in cost and benefits are factors that are mainly discussed in this field. The methods used for CCS project planning are cost curve model and optimization model. The real option approach is suitable for the evaluation of investment decision-making. The evaluation of operational decision is mostly based on optimization model. The future research directions can be summarized as five points: (1) continuously and systematically update the calculated costs in the current research to the unified price of the latest year; (2) calculate the cost curve from the perspective of emission sources; (3) expand the planning region of pipeline network to the country, continent, and even the entire world; (4) pay more attention to the investment assessment of the CCS project that may be implemented with low cost and high return; and (5) analyze the optimal operation mode of CCS in the low-load power system.
\end{abstract}

Keywords: CCS; project planning; investment and operational decision-making; review; bibliometrics

\section{Introduction}

The global climate is undergoing significant changes characterized by warming, which has become a major challenge facing the human race regarding human survival and development in the 21st century. The Fifth Assessment Report of the Intergovernmental Panel on Climate Change (IPCC) indicates that the global average temperature has increased by $0.85^{\circ} \mathrm{C}$ from 1880 to 2012 [1]. The rising temperature seems to be insignificant, but it has a serious impact on the global environment, ecology and economic systems, such as melting glaciers [2], crop yield reduction [3], extinction of marine life [4], reduction of grassland carbon stock [5], increasing extreme climate disasters [6], etc.

$\mathrm{CO}_{2}$ is the most important greenhouse gas causing the greenhouse effect. The Third Assessment Report of the IPCC indicates that the contribution ratio of greenhouse gases to global warming is $60 \%$ for $\mathrm{CO}_{2}, 20 \%$ for $\mathrm{CH}_{4}, 6 \%$ for $\mathrm{N}_{2} \mathrm{O}, 14 \%$ for $\mathrm{CF}_{11}, \mathrm{CFC}_{12}$, etc. [7]. In addition, approximately $69 \%$ 
of global $\mathrm{CO}_{2}$ emissions come from processes such as the combustion and processing of energy [8]. Therefore, reducing energy-related $\mathrm{CO}_{2}$ emissions is a key measure to mitigate climate change.

The need to address climate change has reached a global consensus [9]. Many countries have introduced regulatory policy schemes for carbon reduction [10]. Mitigating climate change can start from three aspects: (1) efficiency improvement, (2) replacing fossil fuels with low-carbon energy, and (3) capture and storage of $\mathrm{CO}_{2}$. Although improving energy efficiency is the fundamental way to reduce greenhouse gas emissions by controlling growth in total energy demand, its potential for reducing emissions is gradually decreasing. The goal of developing low-carbon energy is to reduce emissions by reducing fossil fuel demand. However, the low-carbon energy development in some regions, especially in the low-carbon energy resource-poor regions, is not economically viable in the short term. In the foreseeable future, our world will still rely heavily on fossil energy [11].

Carbon dioxide capture and storage (CCS) technology is a potential approach for mitigating climate change. Overall schematic of carbon capture and storage concept is shown in Figure 1. CCS technology is the key means to achieve emission reduction of large-scale emission point sources, even the only means to reduce emissions in power generation and industrial processes [12]. The captured $\mathrm{CO}_{2}$ from fossil fuel power plants, iron, steel plants, etc. is transported to storage sites such as oil and gas fields, unmineable coal seams, and deep saline aquifers for storage, so as to achieve permanent isolation from the atmosphere. If there is no CCS contribution towards achieving global atmospheric concentrations within a range from 430 to $480 \mathrm{ppm} \mathrm{CO}_{2}$ equivalent, the global emission reduction cost will increase by $138 \%$ from 2015 to 2100 [1]. However, the early capital investment of hundreds of millions or even billions of dollars [13,14], as well as the high operating and maintenance costs [15], coupled with future uncertain emission reduction policies [16], have put enterprises with CCS investment willingness in a dilemma.

For CCS technology, we can mitigate these adverse impacts from three aspects: project planning, investment, and operation. The research on project planning can provide a reference for finding more economically feasible projects to be carried out on a priority basis to promote the development of CCS technology. The research on CCS projects investment and operational decision-making can not only enable investors to understand the investment value, investment opportunity, optimal operation strategy, etc., but can also provide a reference for policy-makers (governments) to formulate policies to promote CCS development [17]. The purpose of this study is to sort out the current status and future trends of the research on CCS project planning and investment and operational decision-making in the form of review.

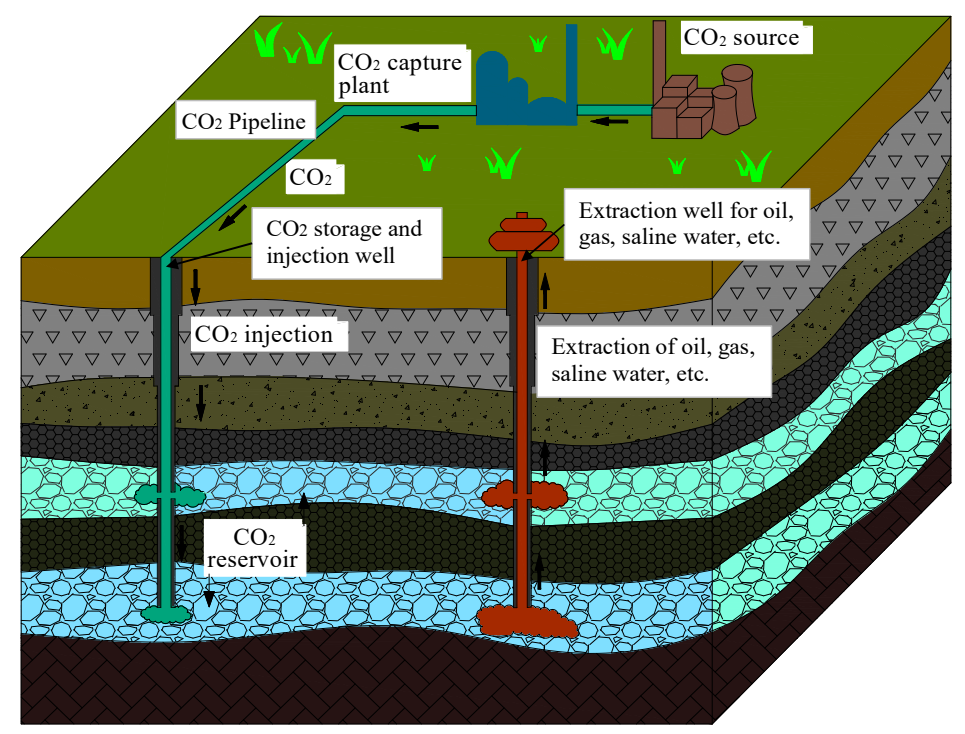

Figure 1. Overall schematic of carbon capture and storage concept. 
Bibliometrics first appeared in 1969 [18]. With the aid of the bibliometrics, the review can present the future research trend, research hotspots, scientific collaborations, etc. At present, bibliometrics is widely used in the review of low-carbon electricity transition [18], low-carbon technology investment [19], and CCS technology evaluation [20,21]. Wang, et al. [18] examined the characteristics of the literature on decarbonization in the power system from 1990 to 2016, and pointed out that low-carbon electricity transition has been highly concerned. Based on the frequency analysis of keywords related to low-carbon technology investment, Yu, et al. [19] found that renewable energy has received much attention, and CCS technology is an emerging low-carbon technology field receiving increasing attention. Karimi and Khalilpour [20] pointed out that research on CCS seems to be closely following the trend of international negotiations on mitigating climate change. Viebahn and Chappin [21] explored the reasons for the huge gap between the scale of the expected CCS assembly and the scale of the actual assembly. This paper reviews the studies on CCS project planning and investment and operational decision-making by a bibliometric analysis.

\section{Research Scope, Methods, and Framework}

\subsection{Research Scope}

At present, CCS technology has developed into three technical fields. The most traditional CCS technology refers to the process of $\mathrm{CO}_{2}$ capture, transportation, and geological storage [22]. Subsequently, based on the consideration of improving economic returns, much research has highlighted the importance of " $\mathrm{CO}_{2}$ utilization" in promoting carbon capture, utilization, and storage (CCUS) technology development $[23,24]$. At the fourth Ministerial Meeting of Carbon Sequestration Leaders Forum (CSLF), "CO ${ }_{2}$ utilization" was included in the CSLF Charter [25]. Compared with CCS, CCUS technology highlights the utilization of $\mathrm{CO}_{2}$ before permanent storage [22]. In recent years, some scholars proposed the concept of carbon capture and utilization (CCU) [26,27], which generally only achieves short-term isolation between $\mathrm{CO}_{2}$ and the atmosphere. In view of the original intention of proposing CCS technology, that is, to mitigate climate change by achieving long-term isolation of $\mathrm{CO}_{2}$ from the atmosphere, we only focus on the research on CCS and CCUS project planning and investment and operational decision-making.

\subsection{Research Methods and Framework}

The Web of Science platform is the largest comprehensive academic information resource database covering almost all subjects in the world, all in all totaling over 33,000 journals [28]. The data were collected from the database of the Science Citation Index Expanded (SCI- Expanded) and Social Sciences Citation Index (SSCI), which was accessed on October 23, 2018. In addition, we set the document type and language as "article" and "English", respectively. After several trial searches, the search query is finally determined as TS $=\left(\left(\mathrm{CCS}\right.\right.$ and $\left.\mathrm{CO}_{2}\right)$ or $\left(\mathrm{CCUS}\right.$ and $\left.\mathrm{CO}_{2}\right)$ or $(\mathrm{CCS}$ and carbon $)$ or (CCUS and carbon) or (CCS and "carbon dioxide") or (CCUS and "carbon dioxide") or "CO capture" or " $\mathrm{CO}_{2}$ transport *" or " $\mathrm{CO}_{2}$ storage" or " $\mathrm{CO}_{2}$ sequestration" or " $\mathrm{CO}_{2}$ capture, utilization and storage" or " $\mathrm{CO}_{2}$ capture and storage" or "carbon capture" or "carbon transport*" or "carbon storage" or "carbon sequestration" or "carbon capture, utilization and storage" or "carbon capture and storage" or "carbon dioxide capture" or "carbon dioxide transport *" or "carbon dioxide storage" or "carbon dioxide sequestration" or "carbon dioxide capture, utilization and storage" or "carbon dioxide capture and storage") And TI = (cost or econom * or incentive or tax or price or curve or investment or "business model *" or "deployment model ${ }^{* \prime}$ ). TS is equivalent to the topic. TI is equivalent to the title. The asterisk $\left(^{*}\right)$ denotes any character group, including null characters. What needs to be explained here is that the research on CCS project planning and investment and operational decision-making is inseparable from the analysis of costs and benefits; thus, the research on CCS technical cost and benefit is also included in the review. One-thousand-four-hundred-and-ninety-five papers were initially 
searched, but some did not match the topic of this study. We conducted a manual search and finally obtained 678 publications, $92 \%$ of which are journal articles and $8 \%$ were conference articles.

For the searched publications, we will start with the review from six aspects as shown in the research framework (Figure 2). The subject and journal distribution helps researchers and readers understand the characteristics and attributes of this research field. The geographical distribution and timeline of publications shows the attention of global and countries and its changes in this field. To a certain extent, the high-yield institutions and high-yield authors reflect their influence in this field. In addition, the researchers' influence can be further evaluated based on the h-index developed by Jorge Hirsch in 2005 [18]. The national and auctorial collaboration is shown in both static and dynamic aspects. The static collaboration is demonstrated by the collaboration network, and the dynamic collaboration analysis requires the help of Equation (1) $[18,19]$. Highly cited papers refer to the top $1 \%$ cited papers in the past ten years, reflecting the influence of the study, which helps identify future research trends to a certain extent. The analysis of research hotspots are an important approach to sort out research objects, research methods, etc. in this field, and identify future research trends and frontiers.

$$
C_{i=1 \text { or } 2}=\frac{\sum_{j=1}^{N} \varphi_{i, j}}{N}
$$

where $C_{i=1}$ or 2 is national or auctorial collaboration degree, respectively; $\varphi_{i, j}$ is the number of countries or authors for each paper; and $N$ is the total number of publications in this field.

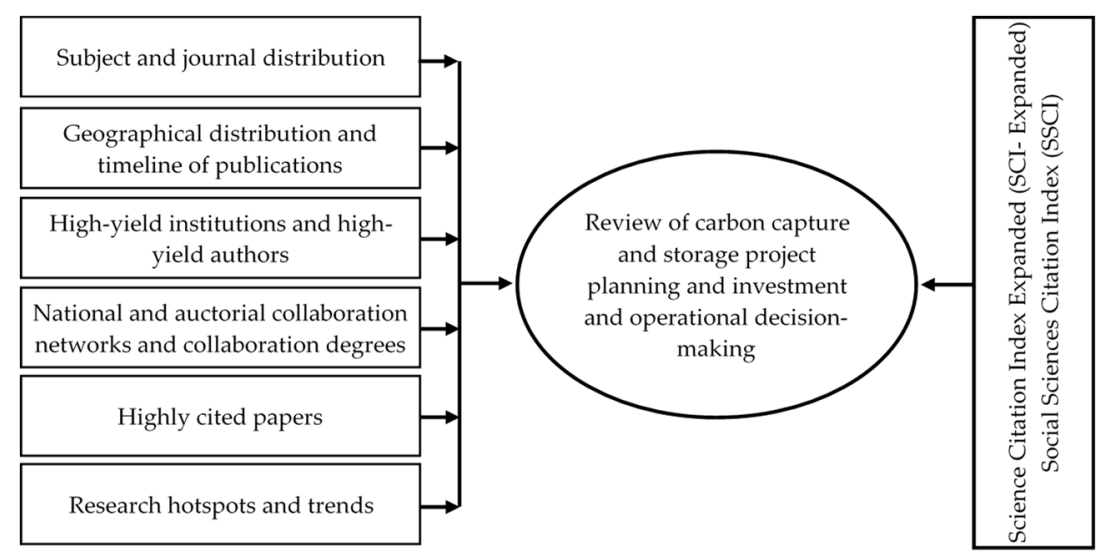

Figure 2. Research framework.

\section{Results and Discussion}

\subsection{Subject and Journal Distribution}

CCS is an interdisciplinary technology, which aims to realize the emission reduction of large-scale emission sources that burn and process fossil fuels $[15,29]$. Therefore, research on CCS project planning and investment and operational decision-making will be positioned in the subjects of Energy Fuels (396) and Green Sustainable Science Technology (153). As shown in Table 1, among the top 10 subjects, Engineering Environmental (191), Environmental Sciences (151), Green Sustainable Science Technology (153), and Environmental Studies (68) are environmental subjects. This is because climate change is an environmental problem [30]. Although the emission reduction potential of CCS technology has been widely recognized, its high cost and high energy consumption hinder its development [31]. Chemical absorption is currently the most mature and widely used capture process, and will be the mainstream capture technology in the short term. The heat consumption for chemical absorbent regeneration in the world's major demonstration projects is as high as $2.6-3.2 \mathrm{GJ} / \mathrm{t} \mathrm{CO} 2$ [32]. $110-150 \mathrm{KWh} / \mathrm{t} \mathrm{CO} 2$ of electricity should be used for running compressors hydraulic pumps, flue gas blowers, etc. [33]. Research and development of more energy-saving and lower-cost capture technologies is a research 
hotspot in the research field of CCS technology, which is also well reflected in the subject distribution (Engineering Chemical (189), Thermodynamics (78), and Chemistry Physical (34)).

The distribution of journals will correspond to the discipline attributes of CCS technology. The International Journal of Greenhouse Gas Control, a professional journal on CCS, has the most articles, accounting for $17.70 \%$ of the total (Table 2). In addition, the publications mainly are published in comprehensive journals related to the subject of Energy Fuels, including Applied Energy, Energy, Energy Policy, Energy Conversion and Management, Fuel and International Journal of Hydrogen Energy. The publications of the six journals account for $27.58 \%$ of the total publications.

Table 1. The 10 most productive subjects.

\begin{tabular}{cccc}
\hline Rank & Subjects & TP & $\boldsymbol{R}$ \\
\hline 1 & Energy Fuels & 396 & $58.41 \%$ \\
2 & Engineering Environmental & 191 & $28.17 \%$ \\
3 & Engineering Chemical & 189 & $27.88 \%$ \\
4 & Green Sustainable Science Technology & 153 & $22.57 \%$ \\
5 & Environmental Sciences & 151 & $22.27 \%$ \\
6 & Thermodynamics & 78 & $11.50 \%$ \\
7 & Environmental Studies & 68 & $10.03 \%$ \\
8 & Economics & 58 & $8.56 \%$ \\
9 & Chemistry physical & 34 & $5.02 \%$ \\
10 & Mechanics & 32 & $4.72 \%$ \\
\hline
\end{tabular}

Note: TP is the number of total publications and $R(\%)$ is the ratio of the number of one subject's publications to the total number of publications.

Table 2. Top 10 productive journals.

\begin{tabular}{ccccc}
\hline Rank & Journals & TP & $\boldsymbol{R}$ & IF (2017) \\
\hline 1 & International Journal of Greenhouse Gas Control & 120 & $17.70 \%$ & 4.078 \\
2 & Applied Energy & 59 & $8.70 \%$ & 7.900 \\
3 & Energy & 41 & $6.05 \%$ & 4.968 \\
4 & Energy Policy & 35 & $5.16 \%$ & 4.039 \\
5 & Energy Conversion and Management & 24 & $3.54 \%$ & 6.377 \\
6 & Industrial \& Engineering Chemistry Research & 23 & $3.39 \%$ & 3.141 \\
7 & Environmental Science \& Technology & 21 & $3.10 \%$ & 6.653 \\
8 & Fuel & 15 & $2.21 \%$ & 4.908 \\
9 & Journal of Cleaner Production & 14 & $2.07 \%$ & 5.651 \\
10 & International Journal of Hydrogen Energy & 13 & $1.92 \%$ & 4.229 \\
\hline
\end{tabular}

Note: TP is the number of total publications; $R(\%)$ is the ratio of the number of one journal's publications to the total number of publications; and IF is the Impact Factor of the journal in 2017.

\subsection{Geographical Distribution and Timeline of Publications}

The timeline of publications in the world is shown in Figure 3. The earliest article in the field was published in 1991 with the title "Technology and cost of recovering and storing carbon dioxide from an integrated-gasifier, combined-cycle plant". Overall, 2004 is a turning point in the number of publications. Before 2004, the number of annual publications was in single digits, without obvious growth. After 2004, the number of annual publications gradually entered an outbreak period, and by 2016, reached 87. 2004 is the time for the inaugural CSLF Ministerial meeting [29], and the time for international organizations such as International Energy Agency Greenhouse Gas R\&D Programme (IEA GHG) and IPCC to issue CCS technology-related reports [15,34-42]. The CSLF is a Ministerial-level international climate change initiative that is focused on the development of improved cost-effective technologies for CCS. The CSLF and international organizations, IEA GHG, IPCC, IEA, etc. play a crucial role in promoting the development of global CCS technology.

From the perspective of timeline of publications, scholars in Europe and the United States paid close attention to this field and carried out active research. The number of USA publications ranked 
first, with 181 articles (Figure 4). The world's first large-scale CCS project was the Val Verde project, launched by the United States in 1972 [13,43]. So far, nine of the 21 large-scale CCS projects in operation or about to be put into operation are in the United States [44]. The number of the United Kingdom (91) and the Netherlands (54) ranked third and fourth, respectively. Before 2006, Chinese scholars began to enter the field. Before 2009, CCS technology received the attention of the Chinese government. A series of state-supported demonstration projects and scientific research projects were launched one after another [24]; thus, the number of publications rapidly increased and ranked second in the world. So far, seven of the 16 large-scale CCS projects in advanced development or early development are in China [44].

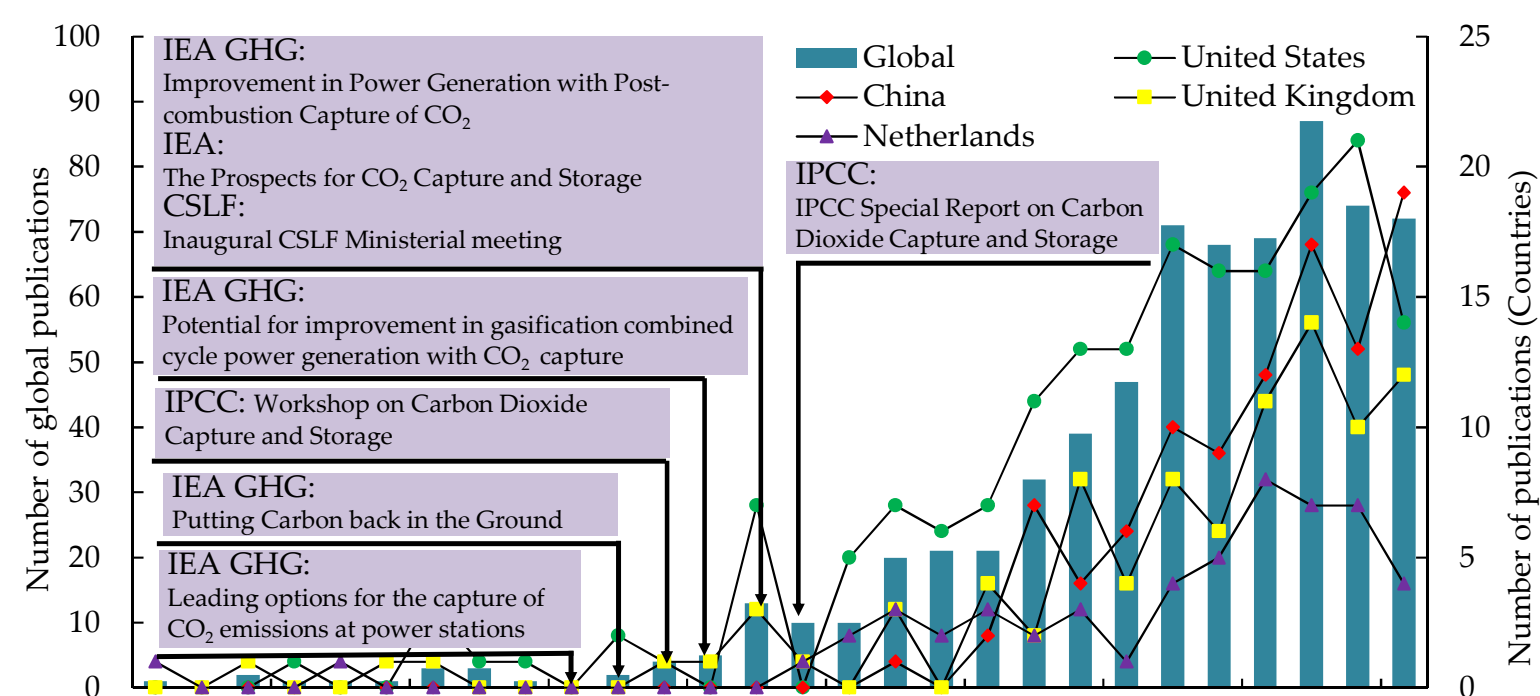

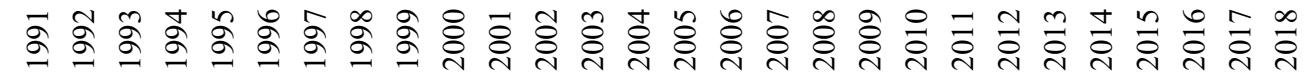

Time (Year)

Figure 3. Timeline of publications in the world and top four countries.

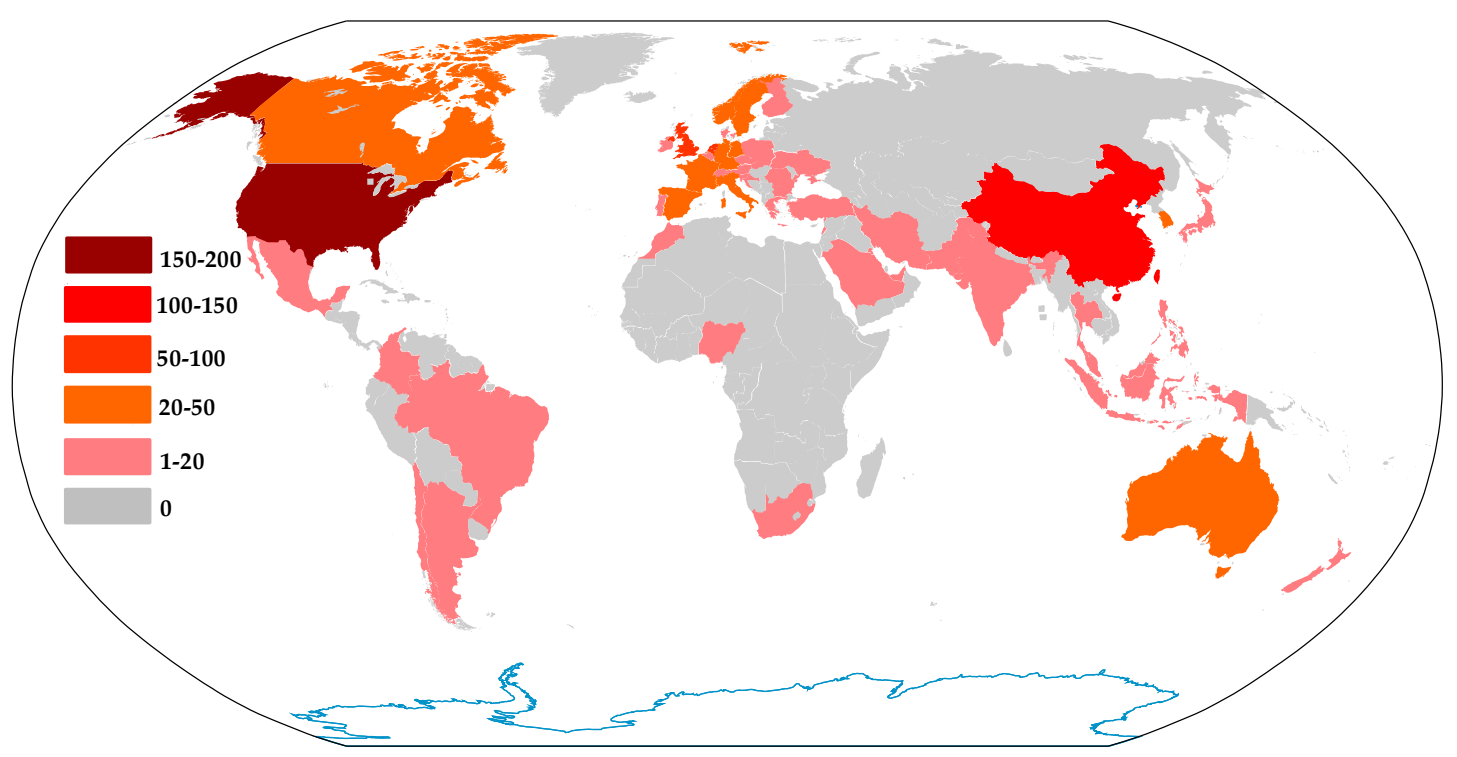

Figure 4. Geographical distributions of publications. 


\subsection{High-Yield Institutions and High-Yield Authors}

The 678 publications were drawn from contributions from 706 institutions, 34 of which contribute to more than $1 \%$ ( $\geq 7$ publications) of the world's publications. High-yield institutions with more than 12 publications are mainly concentrated in the United States, China, and some developed countries in Europe (Table 3), which corresponds well to the publications distribution of the countries. The U.S. Department of Energy and Carnegie Mellon University ranked first and second among all the institutions. The U.S. Department of Energy participates in many CCS projects, and often conducts economic assessments of investment in the CCS projects to determine whether to fund them or not $[13,45]$. Publications from Carnegie Mellon University are mainly contributed by Rubin E and Zhai $\mathrm{H}$, who rank first and eighth among high-yielding authors, respectively. In addition, similar situations exist in high-yield institutions, such as Utrecht University, the University of New South Wales, and Imperial College London, that high-yield authors contribute to almost all publications (Table 4). The Chinese Academy of Sciences and Tsinghua University, respectively, rank fourth and tenth in the top 10 high-yield institutions. These two academic institutions entered the research field early, and then participated in some research and development projects of CCS technology [24].

Table 3. High-yield institutions.

\begin{tabular}{ccccc}
\hline Rank & Institution & TP & $\boldsymbol{R}$ & Country \\
\hline 1 & United States Department of Energy & 39 & $5.75 \%$ & USA \\
2 & Carnegie Mellon University & 29 & $4.28 \%$ & USA \\
3 & Utrecht University & 28 & $4.13 \%$ & Netherlands \\
4 & Chinese Academy of Sciences & 22 & $3.25 \%$ & China \\
5 & Chalmers University of Technology & 16 & $2.36 \%$ & Swedish \\
6 & Norwegian University of Science and Technology & 16 & $2.36 \%$ & Norwegian \\
7 & University of New South Wales & 16 & $2.36 \%$ & Australia \\
8 & Imperial College London & 15 & $2.21 \%$ & UK \\
9 & Consejo Superior de Investigaciones Científicas & 13 & $1.92 \%$ & Spain \\
10 & Tsinghua University & 13 & $1.92 \%$ & China \\
\hline
\end{tabular}

Note: TP is the number of total publications and $R(\%)$ is the ratio of the number of one institution's publications to the total number of publications.

Table 4. High-yield authors.

\begin{tabular}{ccccccc}
\hline Rank & Authors & TP & TC & CPP & H-index & Institution \\
\hline 1 & Rubin E & 18 & 2562 & 142.33 & 16 & Carnegie Mellon University \\
2 & Faaij A & 18 & 755 & 41.94 & 13 & Utrecht University \\
3 & Ramirez A & 15 & 304 & 20.27 & 9 & Utrecht University \\
4 & Wiley D & 13 & 646 & 49.69 & 9 & University of New South Wales \\
5 & Ho M & 12 & 628 & 52.33 & 9 & University of New South Wales \\
6 & Mac dowell N & 10 & 151 & 15.1 & 6 & Imperial College London \\
7 & Cormos C & 9 & 97 & 10.78 & 5 & Babeș-Bolyai University \\
8 & Zhai H & 8 & 204 & 25.05 & 6 & Carnegie Mellon University \\
9 & Shah N & 7 & 136 & 19.63 & 5 & Imperial College London \\
10 & Van den broek M & 7 & 229 & 32.71 & 6 & Utrecht University \\
\hline
\end{tabular}

Note: Institution refers to the first institution that appears in the author's publications; TP is the number of total publications; TC is the number of total citations; and CPP is citations per publication.

\subsection{National and Auctorial Collaboration Networks and Collaboration Degrees}

A collaboration network of 15 countries is shown in Figure 5a. The United States has the largest number of CCS projects in the world, and has rich experience in project planning and investment and operation. Meanwhile, American researchers also pay great attention to CCS technology. Therefore, the United States has closely cooperated with other countries in various aspects, such as research methods and engineering projects [46,47]. Moreover, China and the United States work most closely 
together. Since 2014, "U.S.-China Seminar on $\mathrm{CO}_{2}$ Capture, Utilization and Storage" has been held five times in a row [48]. The EU (European Union) has a holistic planning for the construction of CCS projects or the management of funds related to CCS projects [49,50]. A study may involve the participation or contribution of scholars and governments from different countries $[37,51]$. Therefore, the cooperation among EU countries is particularly close. In addition, from Figure 6, we can find that the global collaboration of research on CCS project planning and investment and operational decision-making is getting closer and closer, and the average national collaboration degree in recent three years has reached 1.51 .

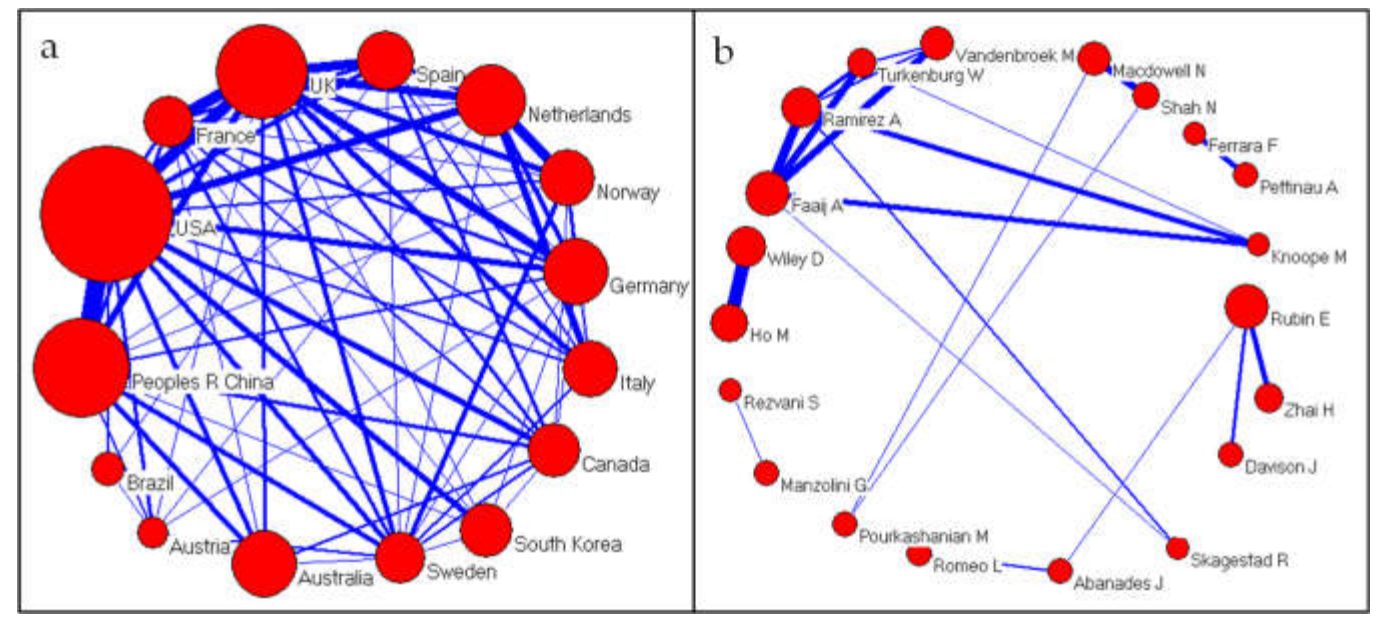

Figure 5. National (a) and auctorial (b) collaboration networks.

The growth rate of auctorial collaboration degree (from 2001 to 2018, increased by 158\%) is shown in Figure 6, is obviously faster than that of national collaboration degree (from 2001 to 2018, increased by $147 \%$ ). This finding suggests that collaboration among researchers around the world is becoming closer and closer, but mainly within countries or institutions. This fact can also be found by reading the coauthored papers is shown in Figure $5 b$. Strengthening the collaboration of global researchers can realize the global sharing of project planning, investment and operational experience, and research and development achievements, so as to accelerate the development of CCS technology worldwide. Therefore, it is important to strengthen the communication of global researchers in various ways.

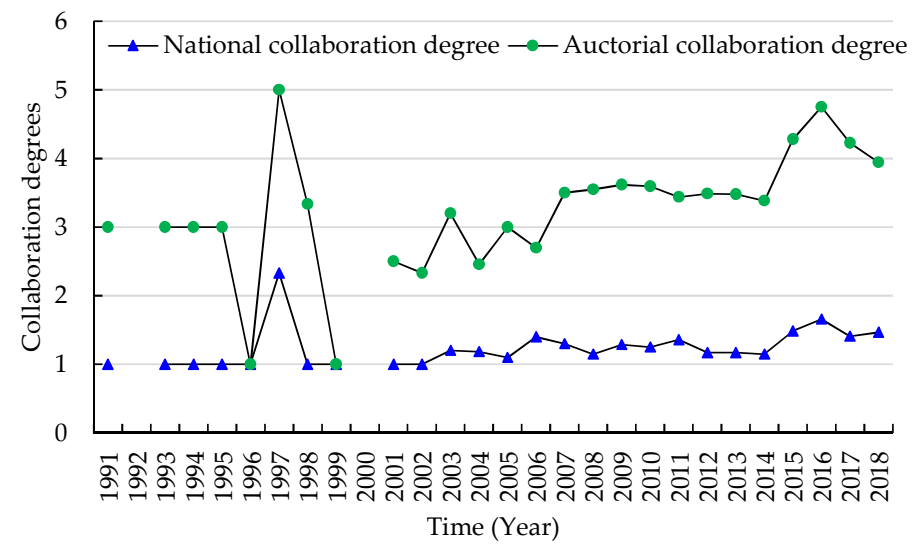

Figure 6. National and auctorial collaboration degrees.

\subsection{Highly Cited Papers}

Table 5 lists the top 10 highly cited papers in this field, with the cited frequency above 54 . A close reading of the 10 articles reveals that they can be divided into six topics: (1) to reduce the $\mathrm{CO}_{2}$ capture 
cost (the 1st, 3rd, 4th, and 10th publications); (2) the impact of CCS technology on energy production costs (the 2nd publication); (3) review of CCS technology cost (the 5th publication); (4) comparison of production cost of different power generation technologies with CCS (the 6th publication); (5) the $\mathrm{CO}_{2}$ utilization costs (the 7th publication); and (6) the economics of flexible operating power plants or power systems with CCS (the 8th and 9th publications). The topics of the highly cited papers show that exploring the low-cost $\mathrm{CO}_{2}$ capture technologies remains the main task in the research field, followed by the low-cost operational approach.

Table 5. Top 10 highly cited papers.

\begin{tabular}{|c|c|c|c|c|}
\hline Rank & $\begin{array}{l}\text { Publications and } \\
\text { Author }\end{array}$ & Publication Year & Title & TC \\
\hline 1 & Ho, et al. [52] & 2008 & $\begin{array}{l}\text { Reducing the cost of } \mathrm{CO}_{2} \text { capture from flue gases } \\
\text { using pressure swing adsorption }\end{array}$ & 270 \\
\hline 2 & van Vliet, et al. [53] & 2009 & $\begin{array}{l}\text { Fischer-Tropsch diesel production in a well-to-wheel } \\
\text { perspective: A carbon, energy flow, and cost analysis }\end{array}$ & 166 \\
\hline 3 & Romeo, et al. [54] & 2008 & $\begin{array}{l}\text { Integration of power plant and amine scrubbing to } \\
\text { reduce } \mathrm{CO}_{2} \text { capture costs }\end{array}$ & 157 \\
\hline 4 & Raynal, et al. [55] & 2011 & $\begin{array}{c}\text { From MEA to demixing solvents and future steps, } \\
\text { a roadmap for lowering the cost of postcombustion } \\
\text { carbon capture }\end{array}$ & 119 \\
\hline 5 & Rubin, et al. [56] & 2015 & The cost of $\mathrm{CO}_{2}$ capture and storage & 110 \\
\hline 6 & Tola and Pettinau [57] & 2014 & $\begin{array}{l}\text { Power generation plants with carbon capture and } \\
\text { storage: A techno-economic comparison between } \\
\text { coal combustion and gasification technologies }\end{array}$ & 84 \\
\hline 7 & Pérez-Fortes, et al. [58] & 2016 & $\begin{array}{c}\text { Methanol synthesis using captured } \mathrm{CO}_{2} \text { as raw } \\
\text { material: Techno-economic and } \\
\text { environmental assessment }\end{array}$ & 76 \\
\hline 8 & Brouwer, et al. [59] & 2015 & $\begin{array}{l}\text { Operational flexibility and economics of power } \\
\text { plants in future low-carbon power systems }\end{array}$ & 72 \\
\hline 9 & Brouwer, et al. [60] & 2016 & $\begin{array}{l}\text { Least-cost options for integrating intermittent } \\
\text { renewables in low-carbon power systems }\end{array}$ & 58 \\
\hline 10 & Li, et al. [61] & 2016 & $\begin{array}{c}\text { Systematic study of aqueous monoethanolamine } \\
\text { (MEA)-based } \mathrm{CO}_{2} \text { capture process: Techno-economic } \\
\text { assessment of the MEA process and } \\
\text { its improvements }\end{array}$ & 54 \\
\hline
\end{tabular}

Note: TC is the number of total citations.

\subsection{Research Hotspots, Gaps, and Trends}

Keywords reflect the core content of the study; we can find research hotspots and trends with an in-depth analysis of them [62,63]. According to the types of keywords, we analyze the research hotspots from four levels: research topics, research objects, internal and external factors introduced, and research methods. After that, we summarized the research gaps and trends in this research field based on a detailed reading of the retrieved publications.

\subsubsection{Research Topics}

CCS technology contains three technical links of $\mathrm{CO}_{2}$ capture, transportation, and storage, which is an emerging technology. The cost of the three technical links varies with $\mathrm{CO}_{2}$ capture objects, transport modes and storage sites, respectively. Therefore, the cost accounting of CCS technology is a must-do and complicated work. In addition, the current CCS technology is accompanied by high capital costs $[13,14]$, high energy consumption $[64,65]$, and other deficiencies. Many researchers are committed to reducing the cost of CCS technology. As a result, there are many publications focusing on the research topic of cost (Table 6). Three cost metrics widely used in existing CCS studies: (1) the levelized cost of 
electricity (LCOE); (2) the cost of $\mathrm{CO}_{2}$ avoided; and (3) the cost of $\mathrm{CO}_{2}$ captured [66,67]. The LCOE focus on the cost of CCS that installed in power plans [68]. The cost of $\mathrm{CO}_{2}$ captured is generally only used to quantify the cost of capturing $\mathrm{CO}_{2}$ [69]. The cost of $\mathrm{CO}_{2}$ avoided must include the whole process cost of CCS, since emissions to the atmosphere are not avoided unless/until the captured $\mathrm{CO}_{2}$ is permanently sequestered [69]. On the basis of the basic perfection of CCS technology cost accounting, many researchers focus on the research on CCS project planning and investment and operational decision-making. The research on CCS project planning can be divided into two aspects: (1) to obtain a cost curve with the comprehensive consideration of the capture sources, storage sites and transport distance in the planning area $[37,46]$ and (2) to achieve the large-scale transportation of $\mathrm{CO}_{2}$ at low cost with the optimization of pipeline network $[70,71]$. Research on operational decision-making focuses on how to achieve economical optimal CCS projects through flexible operations [72,73]. In addition, from the temporal distribution of the four research topics shown in Table 7, the research in this field first focused on cost analysis, followed by project investment evaluation, and the latest is project planning and operation. This does not take into account the time when IPCC, IEA, and other international organizations issue CCS reports on similar topics.

Table 6. Research topics and representative keywords.

\begin{tabular}{ccc}
\hline Research Topics & TK & Representative Keywords (Number) \\
\hline Cost & 78 & $\begin{array}{r}\text { Cost (7); Levelized cost of electricity (5); Cost of } \mathrm{CO}_{2} \\
\text { avoided (4); } \mathrm{CO}_{2} \text { capture cost (4) }\end{array}$ \\
\hline Investment & 11 & Investment (3); CCS investment (3) \\
\hline Planning & 5 & Cost curve (3); $\mathrm{CO}_{2}$ pipeline network (2) \\
\hline Operation & 4 & Flexible operation (3); Operating conditions (1) \\
\hline
\end{tabular}

Note: TK is the total number of occurrences of keywords directly related to a research hotspot. In addition, many keywords, such as economics, techno-economic analysis, etc., have ambiguous topical attributes; thus, they are not listed here.

Table 7. The temporal distribution of research topics.

\begin{tabular}{ccccc}
\hline Time Range & Cost & Planning & Investment & Operation \\
\hline $1991-2000$ & 1 & 0 & 0 & 0 \\
$2001-2010$ & 23 & 0 & 1 & 0 \\
$2011-2018$ & 54 & 5 & 10 & 0 \\
\hline
\end{tabular}

Note: Many keywords, such as economics, techno-economic analysis, etc., have ambiguous topical attributes; thus, they are not used as reference keywords.

\subsubsection{Research Objects}

\section{(1) CCS projects}

1) $\mathrm{CO}_{2}$ capture

The cost of $\mathrm{CO}_{2}$ capture is the highest, usually accounting for $50-80 \%$ of the total cost of CCS [74,75]. Current studies have pointed out that the cost of $\mathrm{CO}_{2}$ capture has great potential to decrease. Taking the cost of postcombustion capture in coal-fired power plants as an example, the cost of $\mathrm{CO}_{2}$ capture in 2050 will decrease by 20-60\% compared with that in 2001 [76]. Therefore, much research focuses on $\mathrm{CO}_{2}$ capture.

In 2000, there were more than 8100 large-scale emission sources ( $>0.1 \mathrm{Mt} /$ year) in the world, and their total emissions (about $15 \mathrm{Gt} \mathrm{CO}_{2}$ ) accounted for more than $60 \%$ of the global anthropogenic $\mathrm{CO}_{2}$ emissions. The emissions from fossil fuels (coal, oil, and gas) power plants accounted for $71 \%$ of the total emissions [77], which has the greatest potential to reduce emissions and is the largest application market of CCS [78,79]. As a result, as many as 127 studies have clearly focused on fossil fuel power plants (Table 8). Negative emissions technologies include biomass energy CCS (BECCS), direct air capture, afforestation, reforestation, etc. [80]. To achieve an average global warming target 
of $2{ }^{\circ} \mathrm{C}$, BECCS needs to contribute $14 \mathrm{Gt}$ of emission reduction during 2013 to 2050 [29]. Therefore, the emission reduction potential and economy of negative emission technologies have become the research hotspots in recent years [81,82]. Although the proportion of $\mathrm{CO}_{2}$ emissions from cement plants $(6 \%)$, refineries $(5 \%)$, and iron and steel plants $(5 \%)$ is small, the contribution to emission reduction is still considerable [77]. Eleven per cent of total emissions are from some industries of high purity $\mathrm{CO}_{2}$, such as ammonia production, ethanol production, ethylene oxide production, natural gas processing units, hydrogen production facilities, etc. [77]. High-purity means that the cost of $\mathrm{CO}_{2}$ capture in these industries is small, which is generally less than USD 15/ton [77,83]. The high-purity sources are potential candidates for early implementation of CCS in the world, especially in China $[15,84]$. This conclusion is obtained by simply considering the $\mathrm{CO}_{2}$ capture cost. If the transportation cost and storage cost are taken into consideration, it will make it more reference value $[46,70]$.

2) $\mathrm{CO}_{2}$ transportation

The captured gaseous $\mathrm{CO}_{2}$ is concentrated to a supercritical state or liquid, and then transported to a storage site. $\mathrm{CO}_{2}$ can be transported by pipeline, ship, road tanker, or rail tanker, and the corresponding transportation technology is relatively mature [33]. Road tankers have low transport capacity and high cost, which are mainly applicable to current small-scale CCS demonstration projects. Railway tankers are still not in use. Pipelines and ships are currently in operation [85], with pipeline transportation technology being the most mature. The global onshore $\mathrm{CO}_{2}$ pipeline has a length of more than 7600 kilometers and a transportation capacity of more than 68 million tons per year $[86,87]$. Pipeline and ship transport methods have the advantage of large transportation capacity and low transportation cost [15], which is key for large-scale $\mathrm{CO}_{2}$ transportation in the future; thus, more attention has been paid to them (Table 8).

3) $\mathrm{CO}_{2}$ utilization and storage

This paper focuses on the research on $\mathrm{CO}_{2}$ geological utilization and storage, the earliest of which is the $\mathrm{CO}_{2}$-EOR $\left(\mathrm{CO}_{2}\right.$-enhanced oil recovery) project, and it has been documented as early as the 1920s [88]. $\mathrm{CO}_{2}$-EOR is currently the most mature, most widely used, and most economical $\mathrm{CO}_{2}$ geological utilization and storage technology [89], and will be the main option for CCS projects in the coming period. Currently, 16 of the 21 large-scale CCS projects in operation, or about to be put into operation, in the world are $\mathrm{CO}_{2}$-EOR projects [90]. Therefore, the keywords related to $\mathrm{CO}_{2}-\mathrm{EOR}$ is the most frequent (14 times). Compared with oil and gas fields and unmineable coal seams, deep saline aquifers are considered to be the best potential reservoirs for $\mathrm{CO}_{2}$ storage because of their large storage capacities and widespread distribution [91]. At present, deep saline aquifers storage projects have been carried out one after another [13]. Other storage sites, such as natural gas field, unmineable coal seams and shale gas fields, have small storage potential or few demonstration projects [92,93], therefore receive less attention (Table 8). Other $\mathrm{CO}_{2}$ utilization technologies belong to CCUS or CCU, including biological $\mathrm{CO}_{2}$ utilization, mineralization of $\mathrm{CO}_{2}$ as inorganic carbonates, etc., have not been reviewed in this study. Many quality review articles of these technologies exist. Both Pan, et al. [94] and Aresta, et al. [95] give a detailed introduction to these technologies.

(2) Other low-carbon power generation technologies

A large amount of energy needs to be used for the operation of CCS technology. The large-scale CCS retrofit in the power system is bound to affect its stability [15]. Besides, the fact that the supply and demand of power systems in many countries or regions, especially those with a large number of photovoltaic power plants, wind power plants, etc. are unstable will lead to frequent adjustment between high and low loads in fossil fuel power plants [96]. In addition, if the energy consumed by CCS is supplied by fossil energy, the depletion of nonrenewable fossil energy will be accelerated [65,97]. The stability of a power system is the foundation of social and economic development [98]. Therefore, to realize the direct coupling of CCS technology with photovoltaic power, wind power and other clean power generation technologies, or to adapt CCS to the unstable power system with a large number of photovoltaic power plants, wind power plants, etc. through flexible control of capture rate, is the current research hotspots (Table 8). Of course, the research in this field cannot be separated 
from the discussion of economy. Taking the national or regional power system as the research object, Cohen, et al. [99] analyze the dispatching mechanism of minimizing the cost through flexible operation of CCS. In addition, there are studies comparing the emission reduction costs of fossil fuel power plants with CCS and other low-carbon power generation technologies [100].

Table 8. Research projects and representative keywords.

\begin{tabular}{|c|c|c|c|c|}
\hline \multicolumn{3}{|c|}{ Research Hotspots } & TK & Representative Keywords (Number) \\
\hline \multirow{15}{*}{ CCS technology } & \multirow{6}{*}{ Capture } & Fossil fuel power plant & 127 & IGCC (18); Coal-fired power plant (10) \\
\hline & & Negative emission technology & 42 & Biomass (13); Negative emissions (4) \\
\hline & & High purity $\mathrm{CO}_{2}$ emission source & 27 & Hydrogen (7); Gasification (7) \\
\hline & & Petroleum refinery & 6 & Refinery (2); Oil refinery(2) \\
\hline & & Iron and steel plant & 5 & Iron and steel (2); Iron and steel industry (2) \\
\hline & & Cement plant & 4 & Cement (2); Cement plant (2) \\
\hline & \multirow{3}{*}{ Transportation } & Pipeline & 14 & Pipeline transport (7); Pipeline transportation (4) \\
\hline & & Ship & 4 & Ship transport (2); Vessel transport (2) \\
\hline & & Rail tanker & 1 & Train-based transport (1) \\
\hline & \multirow{6}{*}{ Storage } & Oil field & 14 & Enhanced oil recovery (5); $\mathrm{CO}_{2}$-EOR (3) \\
\hline & & Deep saline aquifer & 8 & Reverse osmosis (4); Brine concentrate disposal (2) \\
\hline & & Natural gas field & 5 & Natural gas (5) \\
\hline & & Unmineable coal seams & 3 & Underground coal gasification (3) \\
\hline & & Shale gas field & 2 & Shale gas (2) \\
\hline & & Mature and depleted gas fields & 1 & Mature and depleted gas fields (1) \\
\hline \multirow{3}{*}{\multicolumn{2}{|c|}{$\begin{array}{l}\text { Other low-carbon power } \\
\text { generation technologies }\end{array}$}} & Wind power & 3 & Offshore wind (1); Wind energy (1) \\
\hline & & Photovoltaic power & 3 & Solar thermal energy (3) \\
\hline & & Nuclear power & 2 & Nuclear (2) \\
\hline
\end{tabular}

Note: TK is the total number of occurrences of keywords directly related to a research hotspot.

\subsubsection{Internal and External Factors of Evaluation Objects Introduced}

High energy consumption is an important factor of the high cost of CCS projects $[15,101]$. The source, type, and current and uncertain future price of energy consumed by a CCS project will affect its cost, and then affect its investment and operational decision-making $[102,103]$. Uncertainty exists not only in costs, but also in benefits from preferential policies and product sales (Table 9). Capital cost accounts for a large proportion of CCS project cost, generally up to 40-60\% [104,105]. For this reason, many studies put forward the suggestion that the government should give a certain capital subsidy to CCS projects [17,33]. Some countries have already taken positive action [106]. At the same time, the inclusion of CCS projects into other carbon trading systems and the clean development mechanism (CDM), or exemption from carbon tax are seen as the key to incentivizing investment in CCS technology [106]. After several rounds of global climate change negotiations, global climate policy remains uncertain [16]. The uncertainty of global climate policy will be reflected in subsidy policies, $\mathrm{CO}_{2}$ price, etc. Faced with huge uncertainties, investors should avoid the emergence of stranded assets and make the project run effectively based on flexible investment and operational decision-making [107]. In addition, due to the existence of additional energy consumption, possible leakage, etc., the actual emission reduction of CCS is inevitably lower than the amount of captured $\mathrm{CO}_{2}[108,109]$, which in turn affects the investment economy of CCS. The research on CCS project planning mainly considers the cost of CCS project $[37,46]$. 
Table 9. Internal and external factors introduced and representative keywords.

\begin{tabular}{cccc}
\hline \multicolumn{2}{c}{ Research Hotspots } & TK & Representative Keywords (Number) \\
\hline & Cost & 78 & Cost (7); Levelized cost of electricity (5); Cost of $\mathrm{CO}_{2}$ \\
Uncertainty & 15 & avoided (4); $\mathrm{CO}_{2}$ capture cost (4) \\
& Uncertainty (9); Uncertainty analysis (2) \\
Internal factors & 5 & Efficiency penalty (2); Energy consumption (2) \\
& Energy consumption & 3 & Flexible operation (3) \\
& Flexible operation & 3 & Learning curve (3) \\
& Learning curve & Accounting (2) \\
& Accounting & 2 & Stranded assets (2) \\
\hline \multirow{4}{*}{ External factors } & 2 & Carbon price (8); Carbon tax (8); Clean development \\
& Stranded assets & & mechanism (3); Offset schemes(1) \\
& Carbon pricing & & Climate policy (7); Policy (4) \\
& Policy & 17 & Uncertainty (9); Uncertainty analysis (2) \\
& Uncertainty & 15 & Subsidies (2) \\
\hline
\end{tabular}

Note: TK is the total number of occurrences of keywords directly related to a research hotspot.

\subsubsection{Research Methods}

The method of keyword display can be used to study 4 topics: cost accounting, project planning, investment decision-making and optimization of low-carbon power generation technology portfolio and CCS operational decision-making (Table 10). CCS project planning mainly adopts the cost curve method and optimization method [46,70]. The CCS cost curve is the cost of the point-to-point full value chain in all feasible source-sink sets. The constraint condition in the cost curve model is the storage capacity of each storage site. The optimization method used for $\mathrm{CO}_{2}$ pipeline network planning is to realize low-cost transportation of $\mathrm{CO}_{2}$ by replacing the point-to-point pipeline between multiple sources and sinks with a main transport pipeline. CCS technology cost accounting methods mainly include process simulation [110], life cycle assessment [111], levelized cost [100], avoidance cost [56,69], capture cost [15], and thermo-economic analysis [112]. Process simulation is generally used to simulate a process, which is the basis of optimizing the process and reducing the cost of the process [110]. Life cycle assessment generally covers a broader range of assessment, including energy acquisition, transportation, and even the use of electricity [111]. Three cost metrics widely used in existing research on the cost of $\mathrm{CO}_{2}$ capture are (1) the levelized cost, (2) the avoidance cost, and (3) capture cost [67-69]. The levelized cost is often used to characterize the cost of CCS that installed in power plans [68]. The cost of $\mathrm{CO}_{2}$ captured is generally only used to quantify the cost of capturing $\mathrm{CO}_{2}$ [69]. The cost of $\mathrm{CO}_{2}$ avoided must include the whole process cost of CCS, since emissions to the atmosphere are not avoided unless/until the captured $\mathrm{CO}_{2}$ is permanently sequestered [69]. The concept of avoidance cost takes full account of the energy consumption of CCS [113]. Real options and net present value (NPV) methods are currently used to evaluate investment decisions of CCS projects $[114,115]$. However, in comparison, due to the consideration of uncertainty and investment flexibility, the real option method has better applicability in evaluating CCS investment [116,117]. MARKet ALlocation (MARKAL) and optimization methods are used to study the optimization of low-carbon power generation technology portfolio and CCS operation $[118,119]$. Scenario analysis and uncertainty analysis have wide applicability. 
Table 10. Research methods and representative keywords.

\begin{tabular}{ccc}
\hline Research Hotspots & TK & Representative Keywords (Number) \\
\hline Optimization model & 22 & Optimization (12); Optimal design (2) \\
Real options & 20 & Real options (8); Real options analysis (3) \\
Process simulation & 17 & Process simulation (9); Process modelling (4) \\
Life cycle assessment & 15 & Life cycle assessment (8); Life cycle analysis (3) \\
Levelized cost & 10 & Levelized cost of electricity (5); Levelized cost (5) \\
Avoidance cost & 9 & Cost of $\mathrm{CO}_{2}$ avoided (4); $\mathrm{CO}_{2}$ avoidance cost (3) \\
Capture cost & 5 & $\mathrm{CO}_{2}$ capture cost (4); Total capture cost (1) \\
MARKAL & 3 & MARKAL (2); MARKet ALlocation (MARKAL) energy system model (1) \\
Thermo-economic theory & 3 & Thermo-economic analysis (1); Thermo-economic theory (1) \\
Sensitivity analysis & 3 & Sensitivity analysis (3) \\
Scenario analysis & 2 & Scenario analysis (2) \\
NPV & 2 & NPV (2) \\
\hline
\end{tabular}

Note: TK is the total number of occurrences of keywords directly related to a research hotspot.

\subsubsection{Research Gaps and Trends}

(1) Costs of CCS technologies

The accounting of CCS technology costs is the basis for conducting research in this field. In addition, the costs of CCS technology can be used as a reference for policy-makers and investment decision makers to understand CCS technology and related planning and investment issues. However, the time and currency unit of each research are not uniform, which causes inconvenience for many readers to understand the development of CCS technology cost. For this reason, some studies have collated the costs of existing research and unified them into constant 2004 US dollars (USD) [120], or the constant 2013 USD [56,113], etc. With the passage of time and the publication of new research, we should further update the existing research. In addition, the current research in the review is not comprehensive. [113] only reviewed the $\mathrm{CO}_{2}$ capture cost of various industries. [56] unified $\mathrm{CO}_{2}$ capture cost of power plant, transportation cost, and storage cost. [120] made a comparative analysis of the current cost accounting methods of $\mathrm{CO}_{2}$ pipeline transportation and storage.

(2) CCS project planning

1) Cost curve

The drawing of the cost curve is conducive to the development of CCS projects. The CCS cost curve is the cost of the point-to-point full value chain in all feasible source-sink sets. The calculation of the cost curve is mostly based on the method developed by Dahowski in 2001 [121]. At present, the cost curves of CCS technologies in the world [122], North America [42], Europe [37], and China [46] have been systematically analyzed. Specifically, the current research object contains as many of the large-scale emission sources as possible in the study area, as well as all feasible storage sites. However, from the results presented, the above research only presents the cost curve from the perspective of the storage site, but lacks the cost curve from the perspective of the source. This has certain deficiencies in providing reference for CCS project planning at the national or regional level. After all, the CCS project sponsor should be the source of emissions rather than the storage site.

2) $\mathrm{CO}_{2}$ pipeline network

$\mathrm{CO}_{2}$ pipeline network planning is to realize low-cost transportation of $\mathrm{CO}_{2}$ by replacing the point-to-point pipeline between multiple sources and sinks with a main transport pipeline. The research in this field is in its infancy and the planning area of the most existing research is only a subregion of the overall planning level (i.e., country) [70,71]. It would make more sense if the planning area could be expanded to a country, continent or even the world. Of course, this is a huge and complex project, and may even require the joint efforts of scholars or governments in various fields or countries.

(3) CCS project investment

Current studies mostly focus on the evaluation of investment in full-process CCS projects $[17,123,124]$, but some of them focus on the detailed analysis of parameters, cost and benefit of the capture link, ignoring the details of transportation distance and costs, storage sites 
and costs $[123,124]$. The cost uncertainty of the storage link is large, which may have a significant impact on investment decision-making. In addition, in terms of the costs and benefits of capture and storage, capturing $\mathrm{CO}_{2}$ from high-concentration emission sources and using it for enhanced oil recovery is currently the most economical option. Most of the current large-scale CCS projects in operation or about to be operated are such projects [13]. However, research on investment economic evaluation of such projects is relatively lacking.

(4) CCS project operation

The research on CCS technology operation optimization mainly focuses on the power industry [72,125]. Of course, some optimization schemes are also applicable to $\mathrm{CO}_{2}$ capture in industrial processes. Large-scale assembly of CCS technology with high energy consumption power systems will inevitably affect the stability of power system operation. The coupling of CCS technology with other low-carbon power generation technologies or the control of flexible capture rate can weaken the impact of CCS on the operational stability of power systems. However, the impact of the energy consumption of CCS technology on the power system generally only occurs when the power system has high load or large load fluctuations. The operation optimization of CCS technology in the long-term low-load operation power system is currently less concerned. At present, average capacity factors of various power generation technologies in many countries around the world are at a low level, even under $60 \%[126,127]$.

\section{Conclusions}

According to the review of CCS project planning and investment and operational decision-making based on bibliometrics, the following conclusions are drawn.

(1) The subjects related to CCS technology mainly include Energy Fuels, Engineering Environmental, Green Sustainable Science Technology, etc. Therefore, the research on CCS project planning and investment and operational decision-making cannot be separated from these disciplines. In addition, the journal distribution echoes this conclusion. The journals, such as International Journal of Greenhouse Gas Control, Applied Energy, Environmental Science \& Technology, Journal of Cleaner Production, etc. focus on the collection of academic papers on energy, environment, clean energy technology, etc.

(2) International organizations such as the IEA GHG, IPCC, IEA, and CSLF have played an important role in the development of CCS technology. Taking the time for the inaugural CSLF Ministerial meeting, and for IEA GHG, IEA, and IPCC to issue CCS technology-related reports as the node of 2003-2005; with a deepening understanding of the feasibility and emission reduction potential of CCS technology, the number of publications in this research field has undergone rapid growth. In addition, the number of publications in each country is generally closely related to the strength of policy support and the level of project development. After all, whether CCS technology can be supported and valued by the state and enterprises under the background of difficult-to-make profits is related to the needs and values of research. The publications of the United States topped the list, with China ranking second with a rapid increase since 2009.

(3) The publications of the U.S. Department of Energy ranks first among all institutions in terms of its involvement in many CCS projects. In addition, high-yield authors usually come from high-yield institutions, and contribute to almost all the publications of the high-yielding institutions they work for. Besides, collaboration among researchers around the world is becoming closer and closer, but mainly within countries or institutions. We should strengthen the collaboration of global researchers in various ways, because it can promote the development of CCS.

(4) The fossil fuel power generation sector is the industry with the most potential to reduce emissions, pipeline transportation is the most suitable for large-scale transportation, and oil fields are the most mature and economic storage option. Therefore, they are the most concerned objects in the research field, respectively. CCS project planning focuses on the cost of all CCS projects in the planning area. Policies, carbon pricing, and uncertain costs and benefits are key factors influencing investment 
and operational decision-making. The methods used for CCS project planning are cost curve model and optimization model. Real option method is suitable for investment decision-making evaluation. The evaluation of operational decision is mostly based on optimization model.

(5) The cost of existing CCS technology should be continuously and comprehensively updated to a uniform price, which will enable policy-makers and investment decision-makers to better understand CCS technology and related development issues such as planning and investment. The research on CCS project planning can be divided into two aspects: (1) to obtain a cost curve with the comprehensive consideration of the capture sources, storage sites and transport distance and (2) to achieve the large-scale transportation of $\mathrm{CO}_{2}$ at low cost with the optimization of pipeline network. In the field of cost curve research, further research is needed by scholars to shift the assessment perspective from the storage site to the emission sources. In the field of $\mathrm{CO}_{2}$ pipeline network research, it would make more sense if the planning area could be expanded to a country, continent, or even the world. We believe that it is more realistic to focus on the investment assessment of CCS projects that are likely to be implemented early due to lower costs rather than those with the greatest potential for emission reduction. In the research field discussing the optimal operation of CCS projects, the optimization operation research of CCS projects in low-load power systems will be a future research branch.

Author Contributions: All authors have cooperated in the preparation of this work. Conceptualization, J.L.; Data Curation, J.L.; Formal Analysis, J.L., P.W., and B.Y.; Methodology, J.L.; Supervision, Y.H.; Validation, J.L. and Y.H.; Visualization, J.L., P.W., and B.Y.; Writing-Original Draft, J.L.; Writing-Review \& Editing, J.L.

Acknowledgments: The authors gratefully acknowledge financial support from China's National Key R\&D Program (2016YFA0602603) and the National Natural Science Foundation of China (Nos. 71521002 and 71642004). We appreciate our colleagues' support and the help from the BIT Center for Energy and Environmental Policy Research.

Conflicts of Interest: The authors declare no conflict of interest.

\section{References}

1. IPCC (Intergovernmental Panel on Climate Change). Climate Change 2014: Synthesis Report Summary for Policymakers; Cambridge University Press: Cambridge, UK, 2015; ISBN 978-92-9169-143-2.

2. Pelto, M.S. Impact of Climate Change on North Cascade Alpine Glaciers, and Alpine Runoff. Northwest Sci. 2016, 82, 65-75. [CrossRef]

3. Rosenzweig, C.; Parry, M.L. Potential impact of climate change on world food supply. Nature 1994, 367, 133-138. [CrossRef]

4. Hoeghguldberg, O.; Bruno, J.F. The impact of climate change on the world's marine ecosystems. Science 2010, 328, 1523-1528. [CrossRef] [PubMed]

5. Parton, W.J.; Scurlock, J.M.O.; Ojima, D.S.; Schimel, D.S.; Hall, D.O.; Members, S.G. Impact of climate change on grassland production and soil carbon worldwide. Glob. Chang. Biol. 1995, 1, 13-22. [CrossRef]

6. Nordhaus, W.D.; Boyer, J. Warming the World: Economic Models of Global Warming; MIT Press: Cambridge, UK, 2000; ISBN 0262140713.

7. IPCC (Intergovernmental Panel on Climate Change). Climate Change 2001: The Scientific Basis; Cambridge University Press: Cambridge, UK; New York, NY, USA, 2001; ISBN 0521 80767-0.

8. IPCC (Intergovernmental Panel on Climate Change). Climate Change 2007: Mitigation of Climate Change; Cambridge University Press: Cambridge, UK; New York, NY, USA, 2007; ISBN 9780521 88011-4.

9. IPCC (Intergovernmental Panel on Climate Change). Climate Change 2014: Mitigation of Climate Change; Cambridge University Press: Cambridge, UK; New York, NY, USA, 2014; ISBN 978-1-107-05821-7.

10. Abdi, A.; Taghipour, S.; Khamooshi, H. A model to control environmental performance of project execution process based on greenhouse gas emissions using earned value management. Int. J. Proj. Manag. 2018, 36, 397-413. [CrossRef]

11. IEA. World Energy Outlook 2016. International Energy Agency. Available online: https://webstore.iea.org / download/summary /202?fileName=English-WEO-2016-ES.pdf (accessed on 15 November 2018).

12. Haszeldine, R.S. Carbon Capture and Storage: How Green Can Black Be? Science 2009, 325, 1647-1652. [CrossRef] 
13. MIT. CCS Project Database. Massachusetts Institute of Technology. Available online: http:/ / sequestration. mit.edu/tools/projects/index_eor.html (accessed on 11 November 2018).

14. NETL. NETL's Carbon Capture and Storage (CCS) Database_-Version 5. National Energy Technology Laboratory. Available online: https:/ / www.netl.doe.gov/research/coal/carbon-storage/strategic-progra m-support/ database (accessed on 5 November 2018).

15. IPCC (Intergovernmental Panel on Climate Change). IPCC Special Report on Carbon Dioxide Capture and Storage; Cambridge University Press: Cambridge, UK; New York, NY, USA, 2005; ISBN 13 978-0-521-86643-9.

16. Wei, Y.M.; Mi, Z.F.; Huang, Z. Climate policy modeling: An online SCI-E and SSCI based literature review. Omega 2014, 57, 70-84. [CrossRef]

17. Zhang, X.; Wang, X.; Chen, J.; Xie, X.; Wang, K.; Wei, Y. A novel modeling based real option approach for CCS investment evaluation under multiple uncertainties. Appl. Energy 2014, 113, 1059-1067. [CrossRef]

18. Wang, L.; Wei, Y.M.; Brown, M.A. Global transition to low-carbon electricity: A bibliometric analysis. Appl. Energy 2017, 205, 57-68. [CrossRef]

19. Yu, H.; Wei, Y.M.; Tang, B.J.; Mi, Z.; Pan, S.Y. Assessment on the research trend of low-carbon energy technology investment: A bibliometric analysis. Appl. Energy 2016, 184, 960-970. [CrossRef]

20. Karimi, F.; Khalilpour, R. Evolution of carbon capture and storage research: Trends of international collaborations and knowledge maps. Int. J. Greenh. Gas Control 2015, 37, 362-376. [CrossRef]

21. Viebahn, P.; Chappin, E. Scrutinising the Gap between the Expected and Actual Deployment of Carbon Capture and Storage-A Bibliometric Analysis. Energies 2018, 11, 2319. [CrossRef]

22. CSLF. CSLF Technology Roadmap 2017. Carbon Sequestration Leadership Forum. Available online: https:/ / www.cslforum.org/cslf/sites/default/files/CSLF_Technology_Roadmap_2017.pdf (accessed on 5 November 2018).

23. Markewitz, P. Worldwide innovations in the development of carbon capture technologies and the utilization of $\mathrm{CO}_{2}$. Energy Environ. Sci. 2012, 5, 7281-7305. [CrossRef]

24. MOST. Carbon Capture, Utilization and Storage Technology Development in China. Ministry of Science and Technology of the People's Republic of China. Available online: http:/ /www.acca21.org.cn/gest/etc/CCU S_en.pdf (accessed on 13 November 2018). (In Chinese)

25. CSLF. CSLF Technology Roadmap 2013. Carbon Sequestration Leadership Forum. Available online: ht tps:/ / www.cslforum.org/cslf/sites /default/files /CSLF_Technology_Roadmap_2013_0.pdf (accessed on 15 November 2018).

26. Al-Mamoori, A.; Krishnamurthy, A.; Rownaghi, A.A.; Rezaei, F. Carbon Capture and Utilization Update. Energy Technol. 2017, 5, 834-849. [CrossRef]

27. Morales Mora, M.A.; Vergara, C.P.; Leiva, M.A.; Martínez Delgadillo, S.A.; Rosa-Domínguez, E.R. Life cycle assessment of carbon capture and utilization from ammonia process in Mexico. J. Environ. Manag. 2016, 183, 998-1008. [CrossRef] [PubMed]

28. WoS. What if You Could Uncover New Connections in Research with guaranteed Quality, Impact, and Neutrality? Web of Science. Available online: https://clarivate.com/products/web-of-science/ (accessed on 18 November 2018).

29. IEA. 20 Years of Carbon Capture and Storage-Accelerating Future Deployment. International Energy Agency. Available online: https:/ / www.iea.org/publications/freepublications/publication/20-years-ofcarbon-capture-and-storage.html (accessed on 15 November 2018).

30. UNEP. Global Environment Outlook 2000. United Nations Environment Programme. Available online: http:/ / wedocs.unep.org/bitstream/handle/20.500.11822/8219/-Global\%20Environment\%20Out look\%202000\%20-19991609.pdf?isAllowed=y\&sequence=8 (accessed on 15 November 2018).

31. MIT. CCS Project Database: Cancelled and Inactive Projects. Massachusetts Institute of Technology. Available online: http:/ / sequestration.mit.edu/tools/projects/index_cancelled.html (accessed on 16 November 2018).

32. ACCA21 (Administrative Centre for China's Agenda 21). The Global Intellectual Property Analysis of CCUS and Its Important Technologies; Science Press: Beijing, China, 2016; ISBN 978-7-03-048447-5. (In Chinese)

33. IEA. $\mathrm{CO}_{2}$ Capture and Storage: A Key Carbon Abatement Option. International Energy Agency. Available online: http:/ /www.iea.org/publications/freepublications/publication/CCS_2008.pdf (accessed on 4 November 2018). 
34. IEAGHG. Potential for Improvement in Gasification Combined Cycle Power Generation with $\mathrm{CO}_{2} \mathrm{Capture}$ International Energy Agency Greenhouse Gas R\&D Programme. Available online: https:/ /www.ieaghg.org /docs/general_publications/PH4\%20summary\%20small.pdf (accessed on 17 November 2018).

35. IEAGHG. Improvement in Power Generation with Post-combustion Capture of $\mathrm{CO}_{2}$. International Energy Agency Greenhouse Gas R\&D Programme. Available online: http:/ / www.canadiancleanpowercoalition.co m/pdf/AS5\%20-\%20PH4-33\%20post\%20combustion.pdf (accessed on 18 November 2018).

36. IEAGHG. Impact of Impurities on $\mathrm{CO}_{2}$ Capture, Transport and Storage. International Energy Agency Greenhouse Gas R\&D Programme. Available online: https:/ / ieaghg.org/docs/General_Docs/Reports/Ph4 -32\%20Impurities.pdf (accessed on 20 November 2018).

37. IEAGHG. Building the Cost Curves for $\mathrm{CO}_{2}$ Storage: European Sector. International Energy Agency Greenhouse Gas R\&D Programme. Available online: http:/ / www.ieaghg.org/docs/overviews/2005-2.pdf (accessed on 16 November 2018).

38. IEAGHG. Leading Options for the Capture of $\mathrm{CO}_{2}$ at Power Stations. International Energy Agency Greenhouse Gas R\&D Programme. Available online: http://citeseerx.ist.psu.edu/viewdoc/download ;jsessionid=0ED499BB7CFFBF13D178532C53899E60?doi=10.1.1.203.4571\&rep=rep1\&type=pdf (accessed on 19 November 2018).

39. IEAGHG. Putting Carbon back in the Ground. International Energy Agency Greenhouse Gas R\&D Programme. Available online: https://refman.energytransitionmodel.com/publications/439 (accessed on 20 November 2018).

40. IPCC. Workshop on Carbon Dioxide Capture and Storage. Intergovernmental Panel on Climate Change. Available online: https:/ / www.ipcc.ch/pdf/supporting-material/ipcc-workshop-proceedings-cdcs-reg ina-2002.pdf (accessed on 13 November 2018).

41. IEA. Prospects for $\mathrm{CO}_{2}$ Capture and Storage. International Energy Agency. Available online: http://ccs-info .org/onewebmedia/iea_oecd_ccs_prospects.pdf (accessed on 4 November 2018).

42. IEAGHG. Building the Cost Curves for $\mathrm{CO}_{2}$ Storage: North America. International Energy Agency Greenhouse Gas R\&D Programme. Available online: http://hub.globalccsinstitute.com/sites/default / files / publications /50831/2005-03-north-america-storage-cost-curves.pdf (accessed on 15 November 2018).

43. GCCSI. The Global Status of CCS. Special Report: Introducing Industrial Carbon Capture and Storage. Global CCS Institute. Available online: http:/ / hub.globalccsinstitute.com/sites/default/files/publications/ 199858/Introduction\%20to\%20Industrial\%20CCS.pdf (accessed on 17 November 2018).

44. GCCSI. The Global Status of CCS: 2017. Global CCS Institute. Available online: https: / /www.globalccsinstitute.com/sites/www.globalccsinstitute.com/files/uploads/global-status/1-0 _4529_CCS_Global_Status_Book_layout-WAW_spreads.pdf (accessed on 26 October 2018).

45. CRS. Recovery Act Funding for DOE Carbon Capture and Sequestration (CCS) Projects. Congressional Research Service. Available online: https://fas.org/sgp/crs/misc/R44387.pdf (accessed on 4 November 2018).

46. Dahowski, R.T.; Davidson, C.L.; Li, X.C.; Wei, N. A $\$ 70 / \mathrm{t} \mathrm{CO}_{2}$ greenhouse gas mitigation backstop for China's industrial and electric power sectors: Insights from a comprehensive CCS cost curve. Int. J. Greenh. Gas Control 2012, 11, 73-85. [CrossRef]

47. NDRC. China-U.S. Joint Presidential Statement on Climate Change. National Development and Reform Commission. Available online: http:/ / en.ndrc.gov.cn/newsrelease/201509/t20150929_755626.html (accessed on 13 November 2018).

48. NDRC. U.S.-China Seminar on $\mathrm{CO}_{2}$ Capture, Utilization and Storage. National Development and Reform Commission. Available online: http:/ / qhs.ndrc.gov.cn/gzdt/201804/t20180420_883006.html (accessed on 18 November 2018). (In Chinese)

49. NER300. Finance for Installations of Innovative Renewable Energy Technology and CCS in the EU. Available online: http:/ / www.ner300.com/ (accessed on 15 November 2018).

50. Stewart, R.J.; Scott, V.; Haszeldine, R.S.; Ainger, D.; Argent, S. The feasibility of a European-wide integrated $\mathrm{CO}_{2}$ transport network. Greenh. Gases Sci. Technol. 2014, 4, 481-494. [CrossRef]

51. Coussy, P.; Roussanaly, S.; Bureau-Cauchois, G.; Wildenborg, T. Economic $\mathrm{CO}_{2}$ network optimization model COCATE European Project (2010-2013). Energy Procedia 2013, 37, 2923-2931. [CrossRef]

52. Ho, M.T.; Allinson, G.W.; Wiley, D.E. Reducing the cost of $\mathrm{CO}_{2}$ capture from flue gases using pressure swing adsorption. Ind. Eng. Chem. Res. 2008, 47, 4883-4890. [CrossRef] 
53. Van Vliet, O.P.R.; Faaij, A.P.C.; Turkenburg, W.C. Fischer-Tropsch diesel production in a well-to-wheel perspective: A carbon, energy flow and cost analysis. Energy Convers. Manag. 2009, 50, 855-876. [CrossRef]

54. Romeo, L.M.; Bolea, I.; Escosa, J.M. Integration of power plant and amine scrubbing to reduce $\mathrm{CO}_{2}$ capture costs. Appl. Therm. Eng. 2008, 28, 1039-1046. [CrossRef]

55. Raynal, L.; Bouillon, P.-A.; Gomez, A.; Broutin, P. From MEA to demixing solvents and future steps, a roadmap for lowering the cost of post-combustion carbon capture. Chem. Eng. J. 2011, 171, 742-752. [CrossRef]

56. Rubin, E.S.; Davison, J.E.; Herzog, H.J. The cost of $\mathrm{CO}_{2}$ capture and storage. Int. J. Greenh. Gas Control 2015, 40,378-400. [CrossRef]

57. Tola, V.; Pettinau, A. Power generation plants with carbon capture and storage: A techno-economic comparison between coal combustion and gasification technologies. Appl. Energy 2014, 113, 1461-1474. [CrossRef]

58. Pérez-Fortes, M.; Schöneberger, J.C.; Boulamanti, A.; Tzimas, E. Methanol synthesis using captured $\mathrm{CO}_{2}$ as raw material: Techno-economic and environmental assessment. Appl. Energy 2016, 161, 718-732. [CrossRef]

59. Brouwer, A.S.; van den Broek, M.; Seebregts, A.; Faaij, A. Operational flexibility and economics of power plants in future low-carbon power systems. Appl. Energy 2015, 156, 107-128. [CrossRef]

60. Brouwer, A.S.; van den Broek, M.; Zappa, W.; Turkenburg, W.C.; Faaij, A. Least-cost options for integrating intermittent renewables in low-carbon power systems. Appl. Energy 2016, 161, 48-74. [CrossRef]

61. Li, K.; Leigh, W.; Feron, P.; Yu, H.; Tade, M. Systematic study of aqueous monoethanolamine (MEA)-based $\mathrm{CO}_{2}$ capture process: Techno-economic assessment of the MEA process and its improvements. Appl. Energy 2016, 165, 648-659. [CrossRef]

62. Mao, N.; Wang, M.-H.; Ho, Y.-S. A Bibliometric Study of the Trend in Articles Related to Risk Assessment Published in Science Citation Index. Hum. Ecol. Risk Assess. Int. J. 2010, 16, 801-824. [CrossRef]

63. Li, J.; Wang, M.H.; Ho, Y.S. Trends in research on global climate change: A Science Citation Index Expanded-based analysis. Glob. Planet. Chang. 2011, 77, 13-20. [CrossRef]

64. Goto, K.; Yogo, K.; Higashii, T. A review of efficiency penalty in a coal-fired power plant with post-combustion $\mathrm{CO}_{2}$ capture. Appl. Energy 2013, 111, 710-720. [CrossRef]

65. Thorbjörnsson, A. Carbon Capture and Storage: Energy Penalties and Their Impact on Global Coal Consumption. Uppsala University. Available online: http://uu.diva-portal.org/smash/get/diva2: 760450/FULLTEXT01.pdf (accessed on 9 November 2018).

66. IEA. Cost and Performance of Carbon Dioxide Capture from Power Generation. International Energy Agency. Available online: http:/ / www.environmentportal.in/files/costperf_ccs_powergen.pdf (accessed on 23 November 2018).

67. Hammond, G.P.; Akwe, S.S.O.; Williams, S. Techno-economic appraisal of fossil-fuelled power generation systems with carbon dioxide capture and storage. Energy 2011, 36, 975-984. [CrossRef]

68. GCCSI. Toward a common Method of Cost-estimation for $\mathrm{CO}_{2}$ Capture and Storage at Fossil Fuel Power Plants. Global CCS Institute. Available online: http://hub.globalccsinstitute.com/sites/default/files/publi cations / 85761/toward-common-method-cost-estimation-ccs-fossil-fuel-power-plants-white-paper.pdf (accessed on 19 November 2018).

69. Rubin, E.S. Understanding the pitfalls of CCS cost estimates. Int. J. Greenh. Gas Control 2012, 10, 181-190. [CrossRef]

70. Sun, L.; Chen, W. Development and application of a multi-stage CCUS source-sink matching model. Appl. Energy 2017, 185, 1424-1432. [CrossRef]

71. Zhou, D.; Li, P.; Liang, X.; Liu, M.; Wang, L. A long-term strategic plan of offshore $\mathrm{CO}_{2}$ transport and storage in northern South China Sea for a low-carbon development in Guangdong province, China. Int. J. Greenh. Gas Control 2018, 70, 76-87. [CrossRef]

72. Davison, J. Flexible CCS plants-A key to near-zero emission electricity systems. Energy Procedia 2011, 4, 2548-2555. [CrossRef]

73. Qadir, A.; Sharma, M.; Parvareh, F.; Khalilpour, R.; Abbas, A. Flexible dynamic operation of solar-integrated power plant with solvent based post-combustion carbon capture (PCC) process. Energy Convers. Manag. 2015, 97, 7-19. [CrossRef]

74. Qin, C.; Yin, J.; Ran, J.; Li, Z.; Feng, B. Effect of support material on the performance of $\mathrm{K}_{2} \mathrm{CO}_{3}$-based pellets for cyclic $\mathrm{CO}_{2}$ capture. Appl. Energy 2014, 136, 280-288. [CrossRef] 
75. Feron, P.H.M.; Hendriks, C.A. $\mathrm{CO}_{2}$ Capture Process Principles and Costs. Oil Gas Sci. Technol. Rev. IFP 2006, 60, 451-459. [CrossRef]

76. Broek, M.V.D.; Hoefnagels, R.; Rubin, E.; Turkenburg, W.; Faaij, A. Effects of technological learning on future cost and performance of power plants with $\mathrm{CO}_{2}$ capture. Prog. Energy Combust. Sci. 2009, 35, 457-480. [CrossRef]

77. Dooley, J.J.; Dahowski, R.T.; Davidson, C.L.; Wise, M.A.; Gupta, N.; Kim, S.H.; Malone, E.L. Carbon Dioxide Capture and Geologic Storage: A Core Element of a Global Energy Technology Strategy to Address Climate Change. Battelle Memorial Institute. Available online: http:/ / www.globalchange.umd.edu/data/gtsp/doc s/gtsp_reportfinal_2006.pdf (accessed on 31 October 2018).

78. IEA. $\mathrm{CO}_{2}$ Emissions From Fuel Combustion 2017. International Energy Agency. Available online: http:/ / www.iea.org/publications / freepublications/publication/CarbonCaptureandStorageTheso lutionfordeepemissionsreductions.pdf (accessed on 4 November 2018).

79. CoalSwarm/SierraClub/Greenpeace. Boom and Bust 2018: Tracking the Global Coal Plant Pipeline. Available online: http:/ / www.indiaenvironmentportal.org.in/files/file/boomandbust_2018_coalreport.pdf (accessed on 10 November 2018).

80. Smith, P.; Davis, S.J.; Creutzig, F.; Fuss, S.; Minx, J.; Gabrielle, B.; Kato, E.; Jackson, R.B.; Cowie, A.; Kriegler, E. Biophysical and economic limits to negative $\mathrm{CO}_{2}$ emissions. Nat. Clim. Chang. 2016, 6, 42-50. [CrossRef]

81. Ozcan, D.C.; Alonso, M.; Ahn, H.; Abanades, J.C.; Brandani, S. Process and Cost Analysis of a Biomass Power Plant with in Situ Calcium Looping $\mathrm{CO}_{2}$ Capture Process. Ind. Eng. Chem. Res. 2014, 53, 10721-10733. [CrossRef]

82. Moreira, J.R.; Romeiro, V.; Fuss, S.; Kraxner, F.; Pacca, S.A. BECCS potential in Brazil: Achieving negative emissions in ethanol and electricity production based on sugar cane bagasse and other residues. Appl. Energy 2016, 179, 55-63. [CrossRef]

83. GCCSI. Global Costs of Carbon Capture and Storage-2017 Update. Global CCS Institute. Available online: http:/ /hub.globalccsinstitute.com/sites/default/files/publications/201688/global-ccs-cost-upd atev4.pdf (accessed on 29 October 2018).

84. ADB. Roadmap for Carbon Capture and Storage Demonstration and Deployment in the People's Republic of China. Asian Development Bank. Available online: https:/ /www.adb.org/zh/publications/roadmap-ca rbon-capture-and-storage-demonstration-and-deployment-prc (accessed on 18 November 2018).

85. Aspelund, A.; Molnvik, M.J.; Dekoeijer, G. Ship Transport of $\mathrm{CO}_{2}$ Technical Solutions and Analysis of Costs, Energy Utilization, Exergy Efficiency and $\mathrm{CO}_{2}$ Emissions. Chem. Eng. Res. Des. 2006, 84, 847-855. [CrossRef]

86. DOE/NETL. A Review of the $\mathrm{CO}_{2}$ Pipeline Infrastructure in the US. Department of Energy/National Energy Technology Laboratory. Available online: https://www.energy.gov/sites/prod/files/2015/04/f22/QER\%2 0Analysis \%20-\%20A\%20Review\%20of\%20the\%20CO2\%20Pipeline \%20Infrastructure $\% 20 \mathrm{in} \% 20$ the $\% 20$ U.S _0.pdf (accessed on 22 October 2018).

87. GCCSI. The Global Status of CCS: 2016 Summary Report. Global CCS Institute. Available online: http:/ /hub.globalccsinstitute.com/sites/default/files/publications/201158/global-status-ccs-2 016-summary-report.pdf (accessed on 19 November 2018).

88. Khatib, A.K.; Earlougher, R.C.; Kantar, $\mathrm{K} . \mathrm{CO}_{2}$ injection as an immiscible for enhanced recovery in heavy oil reservoirs. SPE Calif. Reg. Meet. 1981. [CrossRef]

89. Garvey, M.A.; McLeroy, P.G.; Weijermars, R. Reservoir-model-based scenarios for assessing the viability of greenhouse gas mitigation strategies through $\mathrm{CO}_{2}$ enhanced oil recovery. Energy Strateg. Rev. 2017, 16, 54-67. [CrossRef]

90. GCCSI. Large-Scale CCS Facilities. Global CCS Institute. Available online: https://www.globalccsinstitute.c $\mathrm{om} /$ projects / large-scale-ccs-projects (accessed on 28 October 2018).

91. Li, Q.; Fei, W.; Liu, X.; Wei, X.; Jing, M.; Li, X. Challenging combination of $\mathrm{CO}_{2}$ geological storage and coal mining in the Ordos basin, China. Greenh. Gases Sci. Technol. 2015, 4, 452-467. [CrossRef]

92. IEAGHG. $\mathrm{CO}_{2}$ Storage in Depleted Gas Fields. International Energy Agency Greenhouse Gas R\&D Programme. Available online: http:/ / hub.globalccsinstitute.com/sites/default/files/publications/9578 6/co2-storage-depleted-gas-fields.pdf (accessed on 22 November 2018).

93. NETL. Using $\mathrm{CO}_{2}$ for Enhanced Coalbed Methane Recovery and Storage. National Energy Technology Laboratory. Available online: https:/ / www.netl.doe.gov / File\%20Library/Research/Carbon-Storage/Proj ect-Portfolio/CBM-June-2014.pdf (accessed on 23 November 2018). 
94. Pan, S.-Y.; Chiang, P.-C.; Pan, W.; Kim, H. Advances in state-of-art valorization technologies for captured $\mathrm{CO}_{2}$ toward sustainable carbon cycle. Crit. Rev. Environ. Sci. Technol. 2018, 48, 471-534. [CrossRef]

95. Aresta, M.; Dibenedetto, A.; Angelini, A. Catalysis for the Valorization of Exhaust Carbon: From $\mathrm{CO}_{2}$ to Chemicals, Materials, and Fuels. Technological Use of $\mathrm{CO}_{2}$. Chem. Rev. 2014, 114, 1709-1742. [CrossRef]

96. Qadrdan, M.; Wu, J.; Jenkins, N.; Ekanayake, J. Operating Strategies for a GB Integrated Gas and Electricity Network Considering the Uncertainty in Wind Power Forecasts. IEEE Trans. Sustain. Energy 2013, 5, 128-138. [CrossRef]

97. Thorbjörnsson, A.; Wachtmeister, H.; Wang, J.; Höök, M. Carbon capture and coal consumption: Implications of energy penalties and large scale deployment. Energy Strateg. Rev. 2015, 7, 18-28. [CrossRef]

98. Darwish, M.; Fantin, J.; Grateloup, G. On the stability of large-scale power systems. J. Cybern. 1977, 7, 159-167. [CrossRef]

99. Cohen, S.M.; Rochelle, G.T.; Webber, M.E. Optimal $\mathrm{CO}_{2}$ Capture Operation in an Advanced Electric Grid. Energy Procedia 2013, 37, 2585-2594. [CrossRef]

100. GCCSI. The Costs of CCS and Other Low-carbon Technologies-Issues Brief 2011. Global CCS Institute. Available online: http:/ / hub.globalccsinstitute.com/sites/default/files/publications/24202/costs-ccs-an d-other-low-carbon-technologies.pdf (accessed on 29 October 2018).

101. Arranz, A.M. Hype among low-carbon technologies: Carbon capture and storage in comparison. Glob. Environ. Chang. 2016, 41, 124-141. [CrossRef]

102. Chu, H.; Ran, L.; Zhang, R. Evaluating CCS Investment of China by a Novel Real Option-Based Model. Math. Probl. Eng. 2016, 2016. [CrossRef]

103. GCCSI. Economic Assessment of Carbon Capture and Storage Technologies: 2011 Update. Global CCS Institute. Available online: http://hub.globalccsinstitute.com/sites/default/files/publication s/12786/economic-assessment-carbon-capture-and-storage-technologies-2011-update.pdf (accessed on 20 November 2018).

104. DOE/NETL. Research and Development Goals for $\mathrm{CO}_{2}$ Capture Technology. Department of Energy/ National Energy Technology Laboratory. Available online: http:/ / citeseerx.ist.psu.edu/viewdoc/download ?doi=10.1.1.365.410\&rep=rep1\&type=pdf (accessed on 11 November 2018).

105. ZEP. The Costs of $\mathrm{CO}_{2}$ Capture: Post-Demonstration CCS in the EU. Zero Emissions Platform. Available online: http:/ / www.zeroemissionsplatform.eu/library/publication/166-zep-cost-report-capture.html (accessed on 27 October 2018).

106. Price, J.P.; McLean, V. Effectiveness of Financial Incentives for Carbon Capture and Storage. International Energy Agency Greenhouse Gas R\&D Programme. Available online: https:/ /ieaghg.org/docs/General_Do CS/Publications/Effectiveness\%20of\%20CCS\%20Incentives.pdf (accessed on 28 October 2018).

107. Zhou, W.; Zhu, B.; Chen, D.; Zhao, F.; Fei, W. How policy choice affects investment in low-carbon technology: The case of $\mathrm{CO}_{2}$ capture in indirect coal liquefaction in China. Energy 2014, 73, 670-679. [CrossRef]

108. IEAGHG. ERM - Carbon Dioxide Capture and Storage in the Clean Development Mechanism. International Energy Agency Greenhouse Gas R\&D Programme. Available online: http: / www.ccsassociation.org/docs/ 2007/2007\%20TR2CCS\%20CDM\%20methodology\%20.pdf (accessed on 29 October 2018).

109. Haefeli, S.; Bosi, M.; Philibert, C. Important accounting issues for carbon dioxide capture and storage projects under the UNFCCC. In Proceedings of the The 7th International Conference on Greenhouse Gas Control, Vancouver, BC, Canada, 5-9 September 2005.

110. Ahmad, F.; Lau, K.K.; Shariff, A.M.; Murshid, G. Process simulation and optimal design of membrane separation system for $\mathrm{CO}_{2}$ capture from natural gas. Comput. Chem. Eng. 2012, 36, 119-128. [CrossRef]

111. NETL. Life Cycle Analysis: Natural Gas Combined Cycle (NGCC) Power Plant. National Energy Technology Laboratory. Available online: https://www.netl.doe.gov/File\%20Library/Research/Energy\%20Analysis /Life\%20Cycle\%20Analysis/NGCC-LCA-Final-Report---Report---9-30-10---Final---Rev-2.pdf (accessed on 22 November 2018).

112. Sheikh, H.M.; Ullah, A.; Hong, K.; Zaman, M. Thermo-economic analysis of integrated gasification combined cycle (IGCC) power plant with carbon capture. Chem. Eng. Process. 2018, 128, 53-62. [CrossRef]

113. Leeson, D.; Dowell, N.M.; Shah, N.; Petit, C.; Fennell, P.S. A Techno-economic analysis and systematic review of carbon capture and storage (CCS) applied to the iron and steel, cement, oil refining and pulp and paper industries, as well as other high purity sources. Int. J. Greenh. Gas Control 2017, 61, 71-84. [CrossRef] 
114. Jahangiri, H.R.; Zhang, D. Optimization of the Net Present Value of Carbon Dioxide Sequestration and Enhanced Oil Recovery; Offshore Technology Conference: Houston, TX, USA, 2011.

115. Cui, H.; Zhao, T.; Wu, R. An Investment Feasibility Analysis of CCS Retrofit Based on a Two-Stage Compound Real Options Model. Energies 2018, 11, 1711. [CrossRef]

116. Huchzermeier, A.; Loch, C.H. Project management under risk: Using the real options approach to evaluate flexibility in R\&D. Manag. Sci. 2001, 47, 85-101.

117. Kulatilaka, N.; Perotti, E.C. Strategic growth options. Manag. Sci. 1998, 44, 1021-1031. [CrossRef]

118. Pattanapongchai, A.; Limmeechokchai, B. $\mathrm{CO}_{2}$ mitigation model of future power plants with integrated carbon capture and storage in Thailand. Int. J. Sol. Energy 2011, 30, S155-S174.

119. Nichols, C.; Victor, N. Examining the relationship between shale gas production and carbon capture and storage under $\mathrm{CO}_{2}$ taxes based on the social cost of carbon. Energy Strateg. Rev. 2015, 7, 39-54. [CrossRef]

120. McCoy, S.T.; Rubin, E.S. An engineering-economic model of pipeline transport of $\mathrm{CO}_{2}$ with application to carbon capture and storage. Int. J. Greenh. Gas Control 2008, 2, 219-229. [CrossRef]

121. Dahowski, R.T.; Dooley, J.J.; Brown, D.R.; Stephan, A.J.; Morsi, B.I. Economic Screening of Geologic Sequestration Options in the United States with a Carbon Management Geographic Information System. 2001. Available online: http:/ / www.globalchange.umd.edu/data/publications/jd0136.pdf (accessed on 11 December 2018).

122. Hendriks, C.; Graus, W.; Bergen, F.V. Global carbon Dioxide Storage Potential and Costs. Ecofys. Available online: https:/ / www.ecofys.com/files/files/ecofys_2004_globalcarbondioxidestorage.pdf (accessed on 12 December 2018).

123. Zhou, W.; Bing, Z.; Fuss, S.; Szolgayová, J.; Obersteiner, M.; Fei, W. Uncertainty modeling of CCS investment strategy in China's power sector. Appl. Energy 2010, 87, 2392-2400. [CrossRef]

124. Szolgayova, J.; Fuss, S.; Obersteiner, M. Assessing the effects of $\mathrm{CO}_{2}$ price caps on electricity investments-A real options analysis. Energy Policy 2008, 36, 3974-3981. [CrossRef]

125. Abdul Manaf, N.; Qadir, A.; Abbas, A. Temporal multiscalar decision support framework for flexible operation of carbon capture plants targeting low-carbon management of power plant emissions. Appl. Energy 2016, 169, 912-926. [CrossRef]

126. EIA. Electric Generator Capacity Factors Vary Widely across the World. U.S. Energy Information Administration. Available online: https: / www.eia.gov / todayinenergy / detail.php?id=22832 (accessed on 3 September 2018).

127. CoalSwarm/SierraClub/Greenpeace. Boom and Bust 2016: Tracking the Global Coal Plant Pipeline. Available online: http:/ / www.environmentportal.in/files/file/Final\%20Boom\%20and\%20Bust\%20report .pdf (accessed on 11 December 2018). 